\title{
PENGARUH UKURAN BIBIT DAN PUPUK ANORGANIK TERHADAP PERTUMBUHAN TANAMAN KELOR (Moringa oleifera)
}

\author{
Rahmi Dianita, Shelly Indriani Naben, Nelly Farida Purba, Ubaidillah, dan A. Rahman Sy. \\ Fakultas Peternakan Universitas Jambi \\ e-mail: rahmi_dianita@yahoo.com
}

\begin{abstract}
ABSTRAK
Ukuran bibit merupakan salah satu cerminan mutu bahan tanaman yang akan menghasilkan produktivitas yang baik jika kebutuhan akan hara untuk pertumbuhannya terpenuhi melalui pemupukan. Penelitian ini bertujuan untuk mengetahui pengaruh ukuran bibit dan pupuk anorganik terhadap pertumbuhan kelor (Moringa oleifera). Penelitian menggunakan rancangan acak lengkap pola faktorial 3x3 dengan 3 ulangan. Faktor pertama adalah ukuran bibit (kecil, sedang dan besar) dan faktor kedua adalah pupuk anorganik (N; N dan P; serta N, P dan K). Ukuran bibit meningkatkan tinggi tanaman pada panen kedua dan jumlah tunas pada panen pertama dipengaruhi oleh ukuran bibit dan penerapan pupuk anorganik pada Moringa oleifera. Sementara itu, tidak terdapat interaksi antara ukuran bibit dan pupuk anorganik terhadap seluruh peubah yang diamati. Disimpulkan bahwa ukuran bibit sedang dan besar dan pemupukan dengan kombinasi lebih dari satu unsur hara (kombinasi N, P dan N, P dan K) menghasilkan pertumbuhan yang terbaik pada Moringa oleifera.
\end{abstract}

Kata kunci: Moringa oleifera, pupuk anorganik, ukuran bibit, pertumbuhan tanaman

\section{EFFECT OF SEEDLING SIZE AND INORGANIC FERTILIZER ON THE GROWTH OF KELOR (Moringa oleifera)}

\begin{abstract}
Seedling size is a reflection of the quality of plant material that will produce good productivity if the nutrients requirement for growth is met through fertilization. This study aimed to determine the effect of seedling size and inorganic fertilizers on the growth of Moringa oleifera. The study used a completely randomized design with a 3×3 factorial pattern with 3 replications. The first factor was seedling size (small, medium and large) and the second factor was inorganic fertilizers ( $\mathrm{N} ; \mathrm{N}$ and $\mathrm{P}$; as well as $\mathrm{N}, \mathrm{P}$ and $\mathrm{K}$ ). Seedling size improved plant height at the second harvest and the number of shoots at the first harvest was affected by seedling size and the application of inorganic fertilizers to Moringa oleifera. Meanwhile, there's no interaction between seedling size and inorganic fertilizers on all variables observed. It was concluded that medium and large seedling size and fertilization with a combination of more than one nutrient (combination of N, P and N, P, K) resulted the best growth of Moringa oleifera.
\end{abstract}

Key words: Moringa oleifera, nitrogen, fosfor, kalium, seedling size

\section{PENDAHULUAN}

Tanaman kelor (Moringa oleifera L.) merupakan tanaman yang mempunyai banyak manfaat karena kandungan nutrisinya yang tinggi dan juga kandungan metabolit sekunder yang merupakan sumber antioksidan. Kandungan protein kasar (berbasis bahan kering) daun M. oleifera berkisar antara 23,0 sampai 30,3\% (Wu et al., 2013). Tanaman kelor kaya akan vitamin dan mineral. Daun kelor adalah bagian tanaman yang paling bergizi dan menjadi sumber penting vitamin $\mathrm{B} 6$ vitamin $\mathrm{C}$, dan provitamin A sebagai beta karoten, magnesium, dan kalsium (Bharali et al., 2003). Oleh karena itu, kandungan nutrisi yang tinggi menjadikan kelor sering dimanfaatkan sebagai pangan terutama sangat baik untuk memperbaiki kondisi malnutrisi pada anak-anak, sebagai obat-obatan, bahan kosmetik dan juga sebagai pakan ternak. Kelor sangat bermanfaat dan dapat digunakan sebagai lorong tanam (alley cropping), pakan ternak, biogas, agen pembersih domestik, pupuk hijau, permen karet, obat-obatan, tanaman hias, dan penjernihan air (Fuglier, 1999). Daun (daun segar dan daun kering), cabang muda, dan sisa biji setelah ekstraksi minyak telah digunakan sebagai pakan ternak (Wu et al., 2013). 
Tanaman kelor masih jarang ditemukan khususnya di kota Jambi (Zulaiha et al., 2020). Potensinya yang sangat baik dari segi nutrisi untuk dimanfaatkan sebagai pakan ternak memberikan prospek untuk pengembangan tanaman kelor ke depan. Budidaya tanaman kelor dapat dilakukan baik secara vegetatif maupun secara generatif. Pengembangbiakan secara generatif menggunakan biji akan menghasilkan bibit kelor yang langsung dapat ditanam di lapangan. Bibit yang baik merupakan jaminan untuk keberhasilan dalam pengembangan tanaman tahunan, termasuk juga tanaman kelor. Mutu bahan tanaman yang baik dapat dilihat dari viabilitas benih, mutu fisik bibit dan pertumbuhan awalnya di lapangan. Mutu fisik dapat dilihat dari kekokohan semai, berat kering total, rasio pucuk akar, dan indeks mutu bibit (Djamhuri et al., 2012).

Kelor dapat dibudidayakan dalam berbagai macam jenis tanah tetapi tumbuh paling baik di lempung yang dikeringkan dengan baik hingga lempung liat, tanah dengan $\mathrm{pH}$ agak asam sampai netral, namun tidak bisa tahan terhadap genangan air yang berkepanjangan (Fuglier, 1999). Meskipun demikian, budidaya tanaman kelor pada tanah ultisol yang mempunyai karakteristik rendah akan hara makro N, P, K dan hara mikro serta bereaksi masam memerlukan manajemen yang baik agar diperoleh produktivitas yang tinggi. Produksi biomassa dengan kualitas nutrisi yang memadai untuk suplementasi pakan rendah kualitasnya bergantung pada faktor manajemen seperti kepadatan tanam, frekuensi dan intensitas pemotongan serta pemupukan (Carlos et al., 2016). Diketahui bahwa ketersediaan dan penyerapan hara oleh tanaman akan lebih cepat dengan menggunakan pupuk anorganik. Biomassa hijau tajuk tanaman merupakan tujuan utama penanaman kelor baik sebagai pangan maupun pakan ternak. Unsur hara nitrogen sangat dibutuhkan dalam fase vegetatif pertumbuhan tanaman kelor. Namun demikian, unsur hara makro lainnya seperti fosfor dan kalium juga dibutuhkan untuk pertumbuhan yang optimal. Status pertumbuhan, hara dan biokimia M. oleifera yang maksimum diperoleh menggunakan pupuk NPK per hektar dengan rasio masing-masing 125: 75: 75 kg dengan waktu panen terbaik pada bulan Agustus (Aslam et al., 2020). Penerapan $0,3 \mathrm{t} \mathrm{ha}^{-1}$ dari formula lengkap (27 kg N, $27 \mathrm{~kg} \mathrm{P}_{2} \mathrm{O}_{5}$ and $36 \mathrm{~kg} \mathrm{~K}_{2} \mathrm{O}$ ) dengan $4 \mathrm{t} \mathrm{ha}^{-1}$ kotoran sapi saat tanam dan campuran $65 \mathrm{~kg}$ urea dengan $2 \mathrm{t} \mathrm{ha}^{-1}$ kotoran sapi setelah setiap pemotongan meningkatkan produksi biomassa daun dan biomassa tanaman utuh (Carlos et al., 2016). Pemberian kotoran unggas secara signifikan meningkatkan pertumbuhan vegetatif tanaman kelor. Konsentrasi nutrisi pada daun kelor juga meningkat secara signifikan dengan mengamademen tanah yang terdegradasi dengan kotoran unggas dibandingkan pupuk NPK, OMF-Organo Mineral Fertilizer (Dania et al., 2014). Berdasarkan latar belakang tersebut dilakukan penelitian untuk mengevaluasi pengaruh ukuran bibit dan penggunaan pupuk anorganik tunggal sumber $\mathrm{N}, \mathrm{P}$, dan $\mathrm{K}$ terhadap pertumbuhan tanaman kelor (Moringa oleifera).

\section{MATERI DAN METODE}

Penelitian ini dilakukan di Laboratorium Hijauan dan Pakan Ternak, Fakultas Peternakan, Universitas Jambi, pada skala rumah kaca pada tahun 2020. Benih kelor yang digunakan diperoleh dari salah satu kebun kelor masyarakat di kota Jambi yang berumur 3 tahun. Polybag dengan kapasitas tanah $10 \mathrm{~kg} / \mathrm{po}-$ libag, tanah ultisol, kapur, pupuk tunggal N (50 kg $\mathrm{ha}^{-1}$ sumber urea $45 \%$ ), P (50 kg ha-1 sumber SP36 36\%) dan $\mathrm{K}$ (50 kg ha-1 sumber $\mathrm{KCl} 60 \%$ ) serta peralatan untuk pemeliharaan dan pemanenan kelor disiapkan.

\section{Prosedur penelitian}

Benih kelor yang telah siap dibungkus dengan kain basah selama 6 jam. Setelah itu, benih disebar dalam polybag nursery untuk dikecambahkan dan menjadi bibit. Sementara itu, tanah ultisol sebagai media tanam yang sudah dimasukkan dalam polybag dikapur (7,5 $\mathrm{g} \mathrm{CaCO}_{3}$ polybag $\left.^{-1}\right)$ dan disiram dan kemudian dibiarkan selama 1 minggu. Setelah itu, pada setiap polybag ditanamkan satu batang paralon yang telah dilubangi setengahnya dari paralon yang panjangnya $25 \mathrm{~cm}$. Paralon ini digunakan untuk pengaliran air pada saat penyiraman tanaman selama penelitian. Hal ini ditujukan agar penyiraman air sampai ke dalam media tanam dan untuk antisipasi pemadatan tanah ultisol pada akhir penelitian.

Setelah kelor berumur 14 hari, bibit kelor dikelompokkan ke dalam 3 ukuran bibit yang berbeda berdasarkan tingginya (ukuran kecil, sedang, dan besar). Kemudian bibit kelor dipindahkan ke dalam polybag yang telah disiapkan dan ditanam tepat di samping paralon. Pada hari kedua setelah bibit dipindahkan dilakukan pemupukan sesuai dengan perlakuan. Pupuk diletakkan dalam lubang yang dibuat di sekitar tanaman dengan jarak yang berjauhan agar tidak tercampur satu dengan lainnya. Tanaman kelor dibiarkan tumbuh selama 90 hari dengan pemeliharaan seperti pembersihan gulma, penyiraman dua kali sehari (pagi dan sore) dan meninjau apabila ada hama. Pada hari ke-6o tanaman kelor dipanen untuk pertama kalinya dan kemudian panen kedua dilakukan 30 hari berikutnya dengan intensitas pemotongan $15 \mathrm{~cm}$. Pemupukan hanya dilakukan satu kali pada awal tanam. 


\section{Rancangan percobaan}

Rancangan yang digunakan adalah RAL pola faktorial $3 \times 3$ dengan 3 ulangan. Faktor pertama adalah ukuran bibit, yaitu: U1 $=$ ukuran kecil $=21 \mathrm{~cm}, \mathrm{U}_{2}=$ ukuran sedang $=24 \mathrm{~cm}, \mathrm{U}_{3}=$ ukuran besar $=26 \mathrm{~cm}$. Faktor kedua adalah jenis pupuk anorganik, terdiri atas: $\mathrm{P} 1=$ nitrogen $\left(50 \mathrm{~kg} \mathrm{ha}^{-1}\right), \mathrm{P}_{2}=$ nitrogen $(50$ $\left.\mathrm{kg} \mathrm{ha}^{-1}\right)$ dan fosfor $\left(5 \mathrm{okg} \mathrm{ha}^{-1}\right), \mathrm{P}_{3}=$ nitrogen $(50$ $\mathrm{kg} \mathrm{ha}^{-1}$ ), fosfor $\left(50 \mathrm{~kg} \mathrm{ha}^{-1}\right)$ dan kalium (50 kg ha-1).

\section{Peubah yang diamati}

Peubah yang diamati dalam penelitian ini adalah tinggi tanaman (cm/tanaman), jumlah tunas (tunas/ tanaman) dan berat kering tajuk (g/tanaman) tanaman kelor yang diukur pada setiap kali panen.

\section{Analisis data}

Data yang diolah adalah data setiap kali panen. Data dianalisis dengan anova dan diuji lanjut dengan menggunakan uji jarak berganda Duncan, apabila ada pengaruh dari perlakuan. Pengolahan data dilakukan dengan perhitungan secara manual di ms. excel lalu diakurasi dengan aplikasi SPSS.

\section{HASIL DAN PEMBAHASAN}

Bibit sebagai bahan tanam sangat menentukan produktivitas hasil tanaman (Santoso et al., 2017). Pemupukan merupakan salah satu cara untuk menambah unsur hara tanah guna mendukung pertumbuhan yang sangat diperlukan bagi tanah yang rendah unsur hara, serta dapat meningkatkan produktivitas tanaman baik dari segi kuantitas maupun kualitasnya (Adhi et al., 2017).

\section{Tinggi tanaman (cm/tanaman)}

Hasil penelitian pada Tabel 1 dan Gambar 1 menunjukkan bahwa kedua faktor perlakuan yaitu ukuran bibit dan pupuk anorganik beserta interaksinya tidak berpengaruh nyata $(\mathrm{P}>0,05)$ terhadap tinggi tanaman kelor (Moringa oleifera) pada panen pertama. Tinggi tanaman pada panen kedua nyata $(\mathrm{P}<0,05)$ dipengaruhi oleh ukuran bibit. Perlakuan U1 (bibit ukuran kecil) berbeda nyata $(\mathrm{P}<0,05)$ dengan perlakuan U2 (bibit ukuran sedang) dan $\mathrm{U}_{3}$ (bibit ukuran besar), Sedangkan perlakuan U2 dan $\mathrm{U} 3$ tidak berbeda nyata $(\mathrm{P}>0,05)$.

Bibit dengan ukuran sedang dan besar menunjukkan tinggi yang terbaik dari M. oleifera. Pertumbuhan tinggi tanaman lebih nyata berbeda pada panen kedua disebabkan tanaman telah mempunyai awal pertumbuhan yang sama. Bibit dengan ukuran sedang dan besar lebih banyak mempunyai cadangan makanan (karbohidrat) di pertumbuhan awal pada panen pertama, sehingga proses metabolismenya le-
Tabel 1 Pengaruh Ukuran Bibit dan Pupuk Anorganik terhadap Tinggi $(\mathrm{cm})$ Tanaman Kelor (Moringa oleifera)

\begin{tabular}{cccc}
\hline $\begin{array}{c}\text { Faktor } \\
\text { Perlakuan }\end{array}$ & Kode Perlakuan & $\begin{array}{c}\text { Tinggi tanaman Tinggi tanaman } \\
\text { Panen } 1\end{array}$ & $\begin{array}{c}\text { Panen } 2 \\
\text { Ukuran bibit }\end{array}$ \\
& U1 & 84,16 & 55, OO $^{\mathrm{a}}$ \\
& $\mathrm{U} 2$ & 85,71 & $59,11^{\mathrm{b}}$ \\
Pemupukan & U3 & 84,17 & $62,56^{\mathrm{b}}$ \\
& P1 & 82,95 & 56,56 \\
& P2 & 84,53 & 57,67 \\
\hline
\end{tabular}

Keterangan:

Superskrip yang berbeda pada kolom yang sama menunjukkan perbedaan yang nyata $(\mathrm{P}<0,05)$. U1= ukuran kecil, U2= ukuran sedang, U3= ukuran besar, $\mathrm{P}_{1}=$ Nitrogen, $\mathrm{P}_{2}=$ Nitrogen dan Phospor, $\mathrm{P}_{3}=$ Nitrogen, Phospor dan Kalium.

bih baik dibandingkan dengan bibit dengan ukuran kecil. Keadaan ini akan memicu pertumbuhan yaitu tinggi tanaman yang lebih cepat. Bibit dengan diameter batang yang lebih besar merupakan pilihan terbaik untuk meningkatkan pertumbuhan awal tanaman (Rose dan Ketchum, 2011).

Sementara itu, perlakuan pemupukan lebih dari satu unsur hara yaitu N, P dan N, P, K memperlihatkan kecenderungan meningkatkan tinggi tanaman kelor baik pada panen pertama maupun pada panen kedua. Tinggi dan lingkar batang kelor yang paling baik diperoleh pada pemupukan $120 \mathrm{~kg} \mathrm{~N}$ : P: $\mathrm{K} \mathrm{ha}^{-1}$ tetapi tidak berbeda nyata dari tanaman kontrol-tanpa pemupukan. Pupuk dapat diterapkan dengan dosis $30 \mathrm{~kg} \mathrm{~N}$ : P: $\mathrm{K} \mathrm{ha}^{-1}$ sedangkan pemupukan dengan dosis $60 \mathrm{~kg} \mathrm{~N}$ : P: $\mathrm{K} \mathrm{ha}^{-1}$ meningkatkan akumulasi fosfor di daun (Isaiah, 2013).

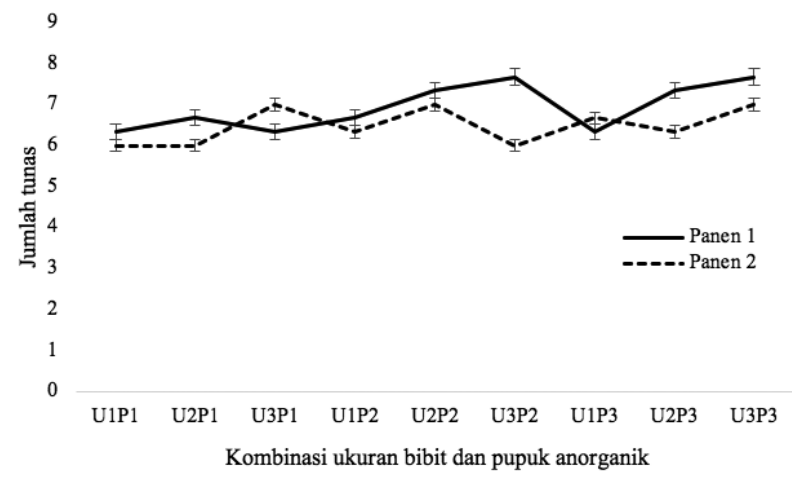

Gambar 1. Interaksi antara ukuran bibit dan pupuk anorganik terhadap tinggi tanaman kelor (Moringa oleifera)

Tinggi tanaman pada panen 60 hari setelah tanam berkisar 77,57-87,63 cm tanaman ${ }^{-1}$. Sementara itu, pencapaian tinggi tanaman pada panen kedua (30 hari) lebih rendah berkisar 55,00 - 66,33 cm tanam$\mathrm{an}^{-1}$. Ukuran bibit yang sedang dan besar menghasilkan tinggi yang lebih baik dibandingkan dengan ukuran kecil. Namun, pemupukan dengan unsur hara yang komplit (N, P, K) menghasilkan tinggi yang lebih baik dibandingkan dengan pemupukan dengan nitrogen saja, meskipun tidak ditemukan interaksi 
dari kedua perlakuan. Meskipun demukian, dari faktor pemupukan, tinggi tanaman pada panen kedua mengalami penurunan sekitar 37,06\% dibandingkan panen pertama. Hal ini kemungkinan disebabkan oleh waktu periode tumbuh yang berbeda. Amaglo et al. (2016) melaporkan tinggi tanaman dengan kepadatan tanam yang berbeda pada umur 60 hari ( 8 minggu) setelah tanam berkisar 73,00 - 88,00 cm tanaman ${ }^{-1}$. Tinggi tanaman tertinggi $155,60 \mathrm{~cm}$ pada minggu ke 10 dihasilkan oleh 5 g N:P:K 15:15:15 sedangkan tanaman terpendek 39,38 cm adalah dihasilkan oleh perlakuan kontrol (Anamayi et al., 2016). Perlakuan $120 \mathrm{~kg} \mathrm{ha}^{-1}$ (NPK) menghasilkan tanaman yang lebih tinggi, lingkar batang, jumlah daun lebih banyak, jumlah cabang lebih banyak dibandingkan perlakuan kontrol dan kombinasi NPK dan kompos pada minggu ke-8 (Sarwar et al., 2018)

\section{Jumlah tunas (tunas/tanaman)}

Hasil analisis ragam pada Tabel 2 menunjukkan bahwa jumlah tunas pada panen pertama nyata $(\mathrm{P}<0,05)$ dipengaruhi oleh ukuran bibit dan penerapan pupuk anorganik pada $M$. oleifera. Sementara itu, Gambar 2 menunjukkan interaksi kedua faktor perlakuan tidak berpengaruh nyata $(\mathrm{P}>0,05)$. Perlakuan U1 (bibit ukuran kecil) berbeda nyata $(\mathrm{P}<0,05)$ dengan perlakuan U2 (bibit ukuran sedang) dan U3 (bibit ukuran besar), sedangkan perlakuan U2 dan $\mathrm{U}_{3}$ tidak berbeda nyata $(\mathrm{P}>0,05)$. Perlakuan $\mathrm{P} 1$ berbeda nyata $(\mathrm{P}<0,05)$ dengan perlakuan $\mathrm{P}_{2}$ dan $\mathrm{P}_{3}$, sedangkan perlakuan $\mathrm{P}_{2}$ dan $\mathrm{P}_{3}$ tidak berbeda nyata $(\mathrm{P}>0,05)$. Pada panen kedua, kedua faktor perlakuan dan interaksinya tidak berpengaruh nyata $(\mathrm{P}>0,05)$ terhadap jumlah tunas.

Stok penanaman (bibit) dengan karakteristik spesifik seperti ukuran besar, rasio akar dengan pucuk tinggi dan nutrisi dan status cadangan karbon yang tinggi berpotensi mengurangi atau melawan kondisi persaingan di lapangan (Grossnickle, 2012; Landha"usser et al., 2012, Cortina et al., 2013). Ukuran bibit yang sedang dan besar kemungkinan mempunyai hasil fotosintesis yang lebih tinggi dibandingkan dengan ukuran bibit yang kecil.

Keunggulan performan dari bibit yang mengandung nutrisi tinggi diperkirakan karena peningkatan translokasi nutrisi ke jaringan yang tumbuh secara aktif (Malik dan Timmer, 1996) seperti tunas. Hal ini juga didukung oleh pemupukan lebih dari satu unsur hara yaitu N, P dan N, P, K. Nitrogen merupakan hara penting pada fase pertumbuhan vegetatif tanaman. Kombinasi lebih dari satu unsur hara yang diberikan disamping nitrogen dapat meningkatkan pertumbuhan tunas tanaman kelor. Fosfor memainkan peran penting dalam proses setiap tumbuhan yang melibatkan transfer energi. Fosfat berenergi
Tabel 2 Pengaruh Ukuran Bibit dan Pupuk Anorganik terhadap Jumlah Tunas Tanaman Kelor (Moringa oleifera)

\begin{tabular}{cccc}
\hline $\begin{array}{c}\text { Faktor } \\
\text { Perlakuan }\end{array}$ & $\begin{array}{c}\text { Jumlah tunas } \\
\text { Panen 1 }\end{array}$ & $\begin{array}{c}\text { Jumlah tunas } \\
\text { Panen 2 }\end{array}$ \\
\hline Ukuran bibit & U1 & $6,44^{\mathrm{a}}$ & 6,33 \\
& U2 & $7,11^{\mathrm{b}}$ & 6,44 \\
Pemupukan & U3 & $7,22^{\mathrm{b}}$ & 6,67 \\
& P1 & $6,44^{\mathrm{a}}$ & 6,33 \\
& P2 & $7,22^{\mathrm{b}}$ & 6,44 \\
& P3 & $7,11^{\mathrm{b}}$ & 6,67 \\
\hline
\end{tabular}

Keterangan:

Superskrip yang berbeda pada kolom yang sama menunjukkan perbedaan yang nyata $(\mathrm{P}<0,05)$. U1 $=$ ukuran kecil, $\mathrm{U}_{2}=$ ukuran sedang, $\mathrm{U}_{3}=$ ukuran besar, $\mathrm{P}_{1}=$ Nitrogen, $\mathrm{P}_{2}=$ Nitrogen dan Phospor, $\mathrm{P}_{3}=$ Nitrogen, Phospor dan Kalium

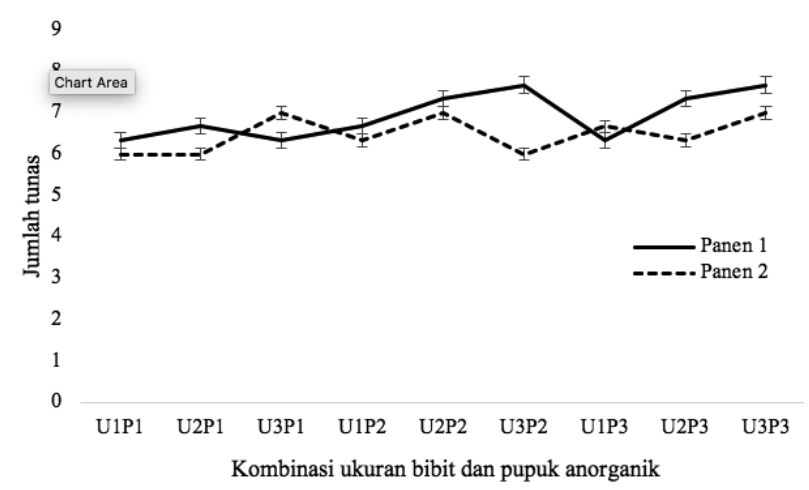

Gambar 2. Interaksi antara ukuran bibit dan pupuk anorganik terhadap jumlah tunas tanaman kelor (Moringa oleifera)

tinggi, sebagai bagian dari struktur kimia adenosin difosfat (ADP) dan ATP, adalah sumber energi yang menggerakkan banyak reaksi kimia di dalam tumbuhan (Armstrong et al., 1999). Kalium berfungsi meningkatkan sintesis dan translokasi karbohidrat, sehingga meningkatkan ketebalan dinding sel dan kekuatan batang. Kalium juga dapat meningkatkan kandungan gula (Hafsi et al., 2014).

\section{Berat kering tajuk (g/tanaman)}

Tabel 3 menunjukkan berat kering tajuk $M$. oleifera pada panen pertama dan panen kedua. Kedua faktor perlakuan serta interaksinya berpengaruh tidak nyata ( $\mathrm{P}>0,05)$ terhadap berat kering tajuk (Gambar 3).

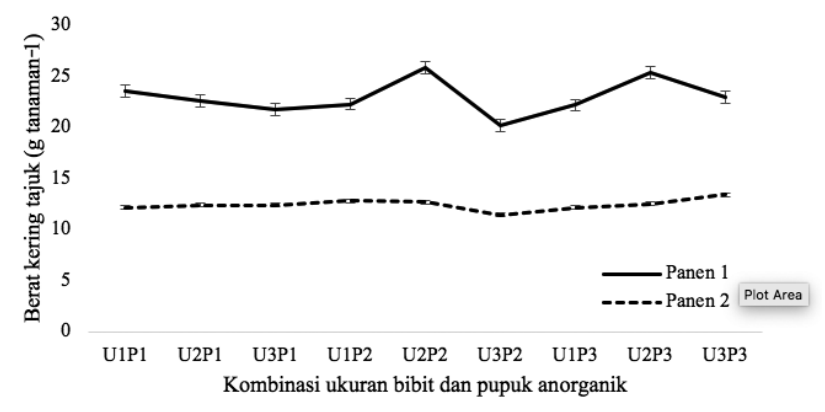

Gambar 3. Interaksi antara ukuran bibit dan pupuk anorganik terhadap berat kering tanaman kelor (Moringa oleifera) 
Tabel 3. Pengaruh ukuran bibit dan pupuk anorganik terhadap berat kering tajuk kelor (Moringa oleifera)

\begin{tabular}{cccc}
\hline $\begin{array}{c}\text { Faktor } \\
\text { Perlakuan }\end{array}$ & $\begin{array}{c}\text { Kode } \\
\text { Perlakuan }\end{array}$ & $\begin{array}{c}\text { Berat kering tajuk } \\
\text { Panen 1 }\end{array}$ & $\begin{array}{c}\text { Berat kering } \\
\text { tajuk Panen 2 }\end{array}$ \\
\hline Ukuran bibit & $\mathrm{U} 1$ & 22,72 & 12,41 \\
& $\mathrm{U} 2$ & 24,67 & 12,54 \\
Pemupukan & $\mathrm{U} 3$ & 21,70 & 12,42 \\
& $\mathrm{P} 1$ & 22,68 & 12,32 \\
& $\mathrm{P} 2$ & 22,84 & 12,33 \\
& $\mathrm{P} 3$ & 23,57 & 12,72 \\
\hline
\end{tabular}

Keterangan:

U1= ukuran kecil, U2= ukuran sedang, $\mathrm{U}_{3}=$ ukuran besar, $\mathrm{P} 1=$ Nitrogen, $\mathrm{P} 2=$ Nitrogen dan Phospor, $\mathrm{P}_{3}=$ Nitrogen, Phospor dan Kalium.

Panen kedua menghasilkan berat kering tajuk kelor yang lebih rendah dibandingkan panen pertama. Berat kering tajuk yang dihasilkan pada panen kedua menurun rata-rata sekitar 45,89\% dibandingkan panen pertama. Panen pertama, tanaman berumur 60 hari ( 8 minggu), sedangkan panen kedua merupakan hasil regrowth tanaman selama 30 hari (4 minggu). Selain itu, kondisi ini juga merupakan indikasi bahwa asupan hara yang secara terus menerus di dalam tanah oleh tanaman tanpa adanya penambahan mengakibatkan pengurasan hara seiring dengan penurunan hasil pucuk dan daun. Selain itu, didukung dengan sifat dari pupuk anorganik yang lebih mudah tersedia dan tercuci. Pucuk segar atau hasil daun berkurang drastis dengan pemanenan yang berkelanjutan. Interval pemotongan 8 minggu menghasilkan biomassa yang lebih tinggi dibandingkan dengan interval pemotongan 4 minggu (Isah et al., 2014). Setelah panen awal pada 60 hari setelah tanam, panen berikutnya harus dilakukan setiap 35 hari dan pemupukan tambahan penting untuk hasil yang baik dan kelangsungan hidup tanaman (Amaglo et al., 2016). Perlakuan pemupukan menunjukkan pemupukan lebih dari satu unsur hara selain nitrogen meningkatkan berat kering tajuk kelor. Pupuk anorganik dengan zat gizi makro dan mikro dapat meningkatkan produksi daun di tanah berpasir (Motis dan Reader, 2019).

\section{SIMPULAN}

Ukuran bibit sedang ( $\left.\mathrm{P}_{2}\right)$ dan besar $\left(\mathrm{P}_{3}\right)$ dan pemupukan dengan kombinasi lebih dari satu unsur hara (kombinasi N, P dan N, P, K) menghasilkan pertumbuhan yang terbaik pada Moringa oleifera. Interaksi antara ukuran bibit dan pemupukan dengan pupuk anorganik tidak ditemukan.

\section{DAFTAR PUSTAKA}

Amaglo, N. K., G. M. Timpo, W.O. Ellis dan R. N. Bennett. 2016. Effect of Spacing and Harvest
Frequency on the Growth and Leaf Yield of kelor Moringa (Moringa oleifera Lam), a Leafy Vegetable Crop. Presented in: Seminar of Moringa and other highly nutritious plant resources: Strategies, standards and markets for a better impact on nutrition in Africa. Ghana, November 16-18, 2006.

Anamayi S. E., O. N. Oladele, R. A. Suleiman, E. Oloyede, and U. Yahaya. 2016. Effects of cow dung and N. P.K fertilizer at different levels on the growth performance and nutrient composition of Moringa oleifera. Annals of Experimental Biology $4(1): 35-39$

Armstrong D. L., K. P. Griffin, M. Danner, J. H. Sultenfuss, W. J. Doyle. 1999. Phosphorus. Better Crops with Plant Food, Vol. 83 No. 1. Potash \& Phosphate Institute, Norcross, Atlanta.

Aslam M. F., S. M. A. Basra, M. B. Hafeez, S. Khan, S. Irshad, S. Iqbal, M. S. Saqqid, M. Z. Akram. 2020. Inorganic fertilization improve quality and biomass of Moringa oleifera L. Agroforestry System 94, p 975-983.

Bharali, R., J. Tabassum, and M. R. H. Azad. 2003. Chemomodulatory effect of Moringa oleifera Lam on hepatic carcinogen metabolising enzymes, antioxidant parameters and skin papilomagenesis in mice. Asian Pacific Journal of Cancer Prevention 4 (2), p. 131-139.

Carlos E. G. González dan G. J. Crespo-López. 2016. Response of Moring a oleifera Lam to fertilization strategies on lixiviated Ferralitic Red soil. Pastos y Forrajes, 39 (3), p 173-177.

Dania S. O., P. Akpansubi, dan O. O. Eghagara. 2014. Comparative effects of different fertilizer sources on the growth and nutrient content of Moringa (Moringa oleifera) seedling in a greenhouse trial. Advances in Agriculture, Hindawi Publishing Corporation. http://dx.doi. org/10.1155/2014/726313

Djamhuri, E., N. Yuniarti, dan H. D. Purwani. 2012. Viabilitas benih dan pertumbuhan awal bibit akasia krasikarpa (Acacia crassicarpa A. Cunn Ex Benth.) dari lima sumber di Indonesia. Jurnal Silvikultur Tropika. 3 (3), p 2086-8227.

Fuglier L. J. 1999. The Miracle Tree: Moringa oleifera, Natural Nutrition for the Tropics, Church World Service, Dakar, Senegal.

Grossnickle S. C. 2012. Why seedlings survive: influence of plant attributes. New For 43. p711-738

Hafsi C, A. Debez, dan A. Chedly. 2014. Potassium deficiency in plants: effects and signaling cascades. Acta Physiologiae Plantarum. 36(5), p 1055-1070

Isah A.D., A.G. Bello, S.A. Zarumaye. 2014. Effects of cutting heights and interval of cutting on 
the yield of Moringa Oleifera (horse raddish). International Journal of Dev. and Sustainability 3(5), p 1147-1151. Sumber: www.isdsnet.com/ijds Isaiah M. A. 2013. Effect of inorganic fertilizer on the growth and nutrient composition of Moringa (Moringa oleifera). Journal of Emerging Trends in Engineering and Applied Sciences 4 (2).

Landha"usser S. M, J. Rodriguez-Alvarez, E. H. Marenholtz, V. J. Lieffers. 2012. Effect of stock type characteristics and time of planting on field performance of Aspen (Populus tremuloides Michx.) seedlings on boreal reclamation sites. New For 43, p 679-693

Malik V dan V. R. Timmer. 1996. Growth, nutrient dynamics, and interspecific competition of nutrient-loaded Black Spruce seedlings on a boreal mixed wood site. Can J for Res 26, p1651-1659
Motis, T. N. and S. M. Reader. 2019. Moringa oleifera leaf production with NPK fertilizer and composted yard waste. Acta Hortic. 1253, p 405412. DOI: 10.17660/ActaHortic. 2019.1253.53

Santoso, B. B., I. Parwata, I., dan I. Soemeinaboedhy. 2017. Pembibitan Tanaman Kelor (Moringa oleifera L.) Arga Puji Press. 79 Halaman.

Sarwar M., J. K. Patra, Jihui B. 2018. Comparative effects of compost and NPK fertilizer on vegetative growth, protein, and carbohydrate of Moringa oleifera lam hybrid PKM-1. Journal of Plant Nutrition 41(12).

Wu D, Z. H. Cai, Y. X. Wei, C. Zhang, G. L. Liang, Q. G. Guo. 2013. Research advances in Moringa as a new plant protein feed. Chin J Anim Nutr. 25, p 503-511.

Zulaiha A. V., Ubaidillah, R. Dianita. 2020. Pengaruh skarifikasi terhadap viabilitas dan vigoritas benih kelor (Moringa oleifera) pada skala rumah kaca. Crop Agro 13(1), p 39-51. 